\title{
Physicochemical Properties and Mineral Composition of Capsicum annum and Capsicum frutescens Oils
}

\author{
Raimi, Monsurat M., Shittu, Suraj A. and Oyetade, Olumide A. \\ Department of Applied Sciences, Osun State Polytechnic, P.M.B. 301, Iree, Nigeria.
}

\begin{abstract}
Physicochemical properties and mineral composition of Capsicum annum and Capsicum frutescens oils were investigated and evaluated using standard methods. The oils extracted from two varieties of each of Capsicum annum and Capsicum frutescens were used for this study. The result obtained for physicochemical properties was refractive index $(1.451$ - 1.439$)$; specific gravity $(0.830-0.751 \mathrm{~g} / \mathrm{cm} 3)$; acid value $(2.693$ $0.785 \mathrm{mg} / \mathrm{g})$ free fatty acid $(1.353-0.395 \mathrm{mg} / \mathrm{g})$; iodine value $(27.920-22.842 \mathrm{mg} / \mathrm{g})$, saponification number $(187.935-117.810 \mathrm{mg} / \mathrm{g})$ and unsaponifiable matter $(2.400-1.473 \%)$. The mineral composition (ppm) result ranged as $\mathrm{Na}(3.40$ - 2.10); K (98.80 - 43.70); Ca (32.00 - 6.00); $\mathrm{Mg}$ (13.20 - 6.00); Zn (0.04 - 0.01); Fe (7.10 2.65); $\mathrm{Cu}$ (1.05 - 0.16); Mn (0.44 - 0.12). Cadmium was detected only in bird eye chilli variety of Capsicum frutescens and Nickel was detected in bird pepper variety of Capsicum frutescens. This study has shown that Capsicum annum and Capsicum frutescens are oil sources with edibility and nutritional qualities as well as industrial applications.
\end{abstract}

Keywords: Capsicum, industrial, mineral, nutrition, physicochemical

\section{Introduction}

Peppers belong to the family Solanaceae, genus Capsicum and species, annum, frustescens or chinense. They are widely used in many parts of the world as a result of their valued sensory attributes, colour, pungency and aroma [1]. Pepper (Chilli) (Capsicum Spp) is widely consumed as spice, vegetable and fruit in many ethnic diets including African, Asian, Hungarian and Mexican [2]. The world production is put at over 19 million tons fresh fruits from 1.5 million hectares with Nigeria being the highest producer in Africa [2]. The following varieties are widely grown in Nigeria and commonly consumed in South West; that is Capsicum frutescens. these are cayenne red pepper, they are known as bird pepper (local name, Ata wewe), cayenne pepper (locally known as Ata sombo) and bird eye chilli pepper (known locally as Ata bawa) and Capsicum annum Bell pepper (tatase) and Sweet pepper (Ata rodo) [3].

Oils and fats used for edible purpose are of either plant or animal origin. At present, the major sources of vegetable oil are seeds of annual plants such as canola, corn, peanut, safflower, soybean and sunflower. A second rich source of vegetable oils is the oil-bearing fruits and nuts of trees such as coconut, palm kernel and olive [4]. Many vegetable oils like olive, groundnut, soybean, corn and cotton seeds are used as cooking oils and also in the manufacture of oleomargarine [5]. Oils and fat are employed in the manufacture of many non-edible products such as paints, and varnishes as well as oil cloth, soaps, printer's ink, polishes, detergents, candles, plastics, synthetic fibers, cosmetics and lubricants. Fixed oil and fats such as castor and cotton oils are used pharmaceutically for their soothing properties [5]. Vegetable oils are reusable. They are used for animal feed and pet food. More recently, waste vegetable oils have been known for their ability to be refined into bio-diesel which can be used like conventional diesel fuel in diesel engines [6].

Vegetable oils contain some metals. Some of these metals like $\mathrm{Na}, \mathrm{K}, \mathrm{Ca}, \mathrm{Mg}, \mathrm{Fe}, \mathrm{Cu}, \mathrm{Zn}$ and $\mathrm{Mn}$ are essential nutrients for human growth while certain forms of these metals can be toxic. The presence of trace metals is an important factor as far as the quality of edible oil is concerned [6]. Minerals are required for normal cellular functions. Minerals are critical for enzyme activation, gene expression, bone formation, hemoglobin composition, and amino acid, lipid along with carbohydrate metabolism. Currently, several human health problems are related to diets. Micronutrients are involved in numerous biochemical processes and an adequate intake of certain micronutrients is necessary for the prevention of deficiency disease [7].The sources of oils and fats is diminishing, this means therefore that there is the growing need for search of new sources of oil as well as exploiting sources that are currently unexploited in order to supplement the existing one [8]. There is an increasing need to perpetually search for oils from non-conventional sources to augment the available ones and also to meet specific applications [9].

This study extracted oils from two varieties each of Capsicum annum (Bell pepper and sweet pepper), and Capsicum frutescens (bird pepper and bird eye chilli pepper), and analysed the physiochemical properties and mineral composition of the oils. 


\section{Materials}

\section{Materials And Methods}

Two varieties of $C$. annum - bell pepper and sweet pepper, and two varieties of $C$. frutescens - bird pepper and bird eye chilli pepper, were used for this study. Fresh matured ripe varieties were bought at Ikirun market, Ikirun, Nigeria. The fresh fruit varieties were thoroughly and carefully washed under running tap water and the pulps were separated from the seeds and stalks manually. The pulps were cut into smaller pieces with sharp knife and oven dried in small batches at $70^{\circ} \mathrm{C}$ for 36 hours. The oven dried samples were ground into fine powder (mesh size 40). The oils were extracted from the oven dried powdered samples with n-hexane using soxhlet extraction method.

\section{Methods}

Physicochemical properties of oil were determined by the methods of A.O.A.C [10]. Mineral composition parameters were determined according to the methods described by Gafar et al., [11]. All analyses were done in triplicate and reagents used were of analytical grade. Result values of different parameters were expressed as the mean value \pm standard deviation.

\section{Results}

The results of the physicochemical properties and mineral composition of Capsicum annum and Capsicum frutescens oils are as shown in Tables 1 and 2 respectively.

Table 1: Physiochemical characteristics of Capsicum annum and Capsicum frutescens oils

\begin{tabular}{llccc}
\hline Parameter & $\begin{array}{l}\text { C. annum } \\
\text { (Sweet pepper) }\end{array}$ & $\begin{array}{l}\text { C. annum } \\
\text { (Bell pepper) }\end{array}$ & $\begin{array}{l}\text { C.frutescens } \\
\text { (Bird eye chilli) }\end{array}$ & $\begin{array}{l}\text { C. frutescens } \\
\text { (Bird pepper) }\end{array}$ \\
\hline $\begin{array}{l}\text { Refractive } \\
\text { Index }\end{array}$ & $1.439 \pm 0.01$ & $1.428 \pm 0.00$ & $1.428 \pm 0.00$ & $1.451 \pm 0.01$ \\
$\begin{array}{l}\text { Specific } \\
\left.\text { gravity (g/cm }{ }^{3}\right)\end{array}$ & $0.802 \pm 0.01$ & $0.751 \pm 0.01$ & $0.765 \pm 0.01$ & $0.830 \pm 0.01$ \\
$\begin{array}{l}\text { Acid value } \\
\text { (mg/g) }\end{array}$ & $0.785 \pm 0.01$ & $1.346 \pm 0.10$ & $1.122 \pm 0.10$ & $2.693 \pm 0.11$ \\
$\begin{array}{l}\text { Free fatty } \\
\text { acid (mg/g) }\end{array}$ & $0.395 \pm 0.02$ & $0.680 \pm 0.02$ & $0.564 \pm 0.10$ & $1.353 \pm 0.20$ \\
$\begin{array}{l}\text { Iodine value } \\
\text { (mg/g) }\end{array}$ & $27.920 \pm 0.20$ & $17.770 \pm 0.11$ & $25.380 \pm 0.22$ & $22.842 \pm 0.10$ \\
$\begin{array}{l}\text { Saponification } \\
\text { number (mg/g) }\end{array}$ & $138.250 \pm 0.23$ & $147.263 \pm 0.02$ & $117.81 \pm 0.30$ & $187.935 \pm 0.21$ \\
$\begin{array}{l}\text { Unsaponifiable } \\
\text { matter (mg/g) }\end{array}$ & $1.780 \pm 0.11$ & $1.890 \pm 0.04$ & $1.473 \pm 0.05$ & $2.400 \pm 0.05$ \\
\hline
\end{tabular}

Values are mean of triplicate determinations \pm standard deviation (S.D) 
Table 2: Mineral composition of Capsicum annum and Capsicum frutescens oils

\begin{tabular}{lllll}
\hline $\begin{array}{l}\text { Parameter } \\
(\mathrm{ppm})\end{array}$ & $\begin{array}{l}\text { C. annum } \\
\text { (Sweet pepper) }\end{array}$ & $\begin{array}{l}\text { C. annum } \\
\text { (Bell pepper) }\end{array}$ & $\begin{array}{l}\text { C. frutescens } \\
\text { (Bird eye chilli) }\end{array}$ & $\begin{array}{l}\text { C. frutescens } \\
\text { (Bird pepper) }\end{array}$ \\
\hline $\mathrm{Na}$ & $3.40 \pm 0.01$ & $6.10 \pm 0.01$ & $2.10 \pm 0.02$ & $3.40 \pm 0.04$ \\
$\mathrm{~K}$ & $43.70 \pm 0.13$ & $49.10 \pm 0.06$ & $57.20 \pm 0.30$ & $98.80 \pm 0.15$ \\
$\mathrm{Ca}$ & $8.00 \pm 0.01$ & $6.00 \pm 0.02$ & $30.00 \pm 0.03$ & $32.00 \pm 0.03$ \\
$\mathrm{Mg}$ & $9.60 \pm 0.01$ & $6.00 \pm 0.01$ & $18.00 \pm 0.10$ & $13.20 \pm 0.10$ \\
$\mathrm{Zn}$ & $0.01 \pm 0.00$ & $0.02 \pm 0.00$ & $0.10 \pm 0.01$ & $0.04 \pm 0.00$ \\
$\mathrm{Fe}$ & $9.00 \pm 0.01$ & $17.10 \pm 0.00$ & $17.10 \pm 0.02$ & $2.65 \pm 0.01$ \\
$\mathrm{Cd}$ & $\mathrm{ND}$ & $\mathrm{ND}$ & $0.01 \pm 0.00$ & $\mathrm{ND}$ \\
$\mathrm{Ni}$ & $\mathrm{ND}$ & $\mathrm{ND}$ & $\mathrm{ND}$ & $0.04 \pm 0.00$ \\
$\mathrm{Cu}$ & $0.30 \pm 0.00$ & $0.16 \pm 0.00$ & $0.26 \pm 0.01$ & $1.05 \pm 0.00$ \\
$\mathrm{Mn}$ & $0.12 \pm 0.01$ & $0.15 \pm 0.00$ & $0.44 \pm 0.02$ & $0.39 \pm 0.00$
\end{tabular}

Values are mean of triplicate determinations \pm standard deviation (S.D) ; ND $\equiv$ not detected

\section{Discussion}

The result for the physicochemical properties of Capsicum annum and Capsicum frutescens oils is as shown in Table 1. The refractive index value varied from 1.451 $\pm 0.01-1.439 \pm 0.010$ in the oils. Refractive index is used by most processors to measure the change in unsaturation as the fat or oil is hydrogenated. The refractive index of oils depends on their molecular weight fatty acid chain length, degree of unsaturation and degree of conjugation [12 ]. The refractive index values obtained for the oils in this study was similar to those reported for pumpkin seed oil (1.4662 \pm 0.0001$)$ [12 ] and melon seed oil (1.4662), soybean oil (1.466-1.470) and corn (1.465-1.468) [13], desma seed oil (1.464) [14] and water melon seed oil (1.47) [15]. Pure oils have marked ranges of refractive index and density, thus the degree of variation of a typical oil from its true values may indicate its relative purity [12 ]. The specific gravity values ranged from $0.830 \pm 0.01 \mathrm{~g} / \mathrm{cm} 3$ to $0.751 \pm 0.01 \mathrm{~g} / \mathrm{cm}^{3}$. The values earlier reported for desma and water melon seed oils were 0.920 [14] and 0.85 [15] respectively.

The acid value obtained for Capsicum annum and Capsicum frutescens oils was in the range, 62.693$0.785 \mathrm{mg} / \mathrm{g}$. Acid value determination is often used as a general indication of the condition and edibility of the oil. This is because an increase in acid value is accompanied by development of objectionable flavours and odours [6]. Acid value is used as an indicator for edibility of oil and suitability for use in the paint industry [9]. Acid value of the oil suitable for edible purpose should not exceed $4 \mathrm{mg} \mathrm{KOH} / \mathrm{g}[5]$. The free fatty acid values were in the range $1.353-0.395 \mathrm{mg} / \mathrm{g}$. Earlier studies reported $1.03 \pm 0.16$ and $1.49 \pm 0.06$ for Cocos nucifera and Colocynthis citrullus oils [9], and $4.77 \pm 0.13,5.0 \pm 0.20$ and $3.74 \pm 0.9$ for Jatropha curcas (L), Cola rostrata and Abelmoschus esculentus oils respectively [5]. The free fatty acid content reported for pumpkin seed oil was $0.39 \pm 0.01$ [13]. Acid value and free fatty acid value are two parameters for edibility of oil [5]. The low acid values and low free fatty acid values obtained in this study for the oils are markers of an acceptable initial quality for the oils. The Capsicum annum and Capsicum frutescens oils are thus edible oils and can be used for cooking purposes, and sources of raw materials for industries.

The result of the iodine values ranged from $27.920 \pm 0.20$ to $17.770 \pm 0.11 \mathrm{mg} / \mathrm{g}$. The iodine value represents the degree of unsaturation. The higher the iodine value is the greater is the unsaturation of specific oil or fat [16]. A good drying oil should have iodine value of 180 [9]. Drying oil dry rapidly on contact with 
atmospheric oxygen and makes the oil useful on commercial scale for paint and varnishes, oil paints [17]. Thus, the iodine values obtained in this study classify the Capsicum annum and Capsicum frutescens oils as non drying oils. Though they may not be suitable as alkyl resins for paint formulations or use as varnishes; they may however found uses in conjunction with amino resins as finishes for certain appliances and in this case the oils can act as plasticizers [9].

The Capsicum annum and Capsicum frutescens oils have saponification number values in the range $187.935-117.810 \mathrm{mg} \mathrm{KOH} / \mathrm{g}$. The saponification value of fat or oil gives an idea of the fatty acid constituents in a fat since with long chain fatty acid constituents in a fat, lower saponification values are obtained per gramme fat [18]. Saponification number is an indication of the amount of fatty saponifiable material in oil or fat. It gives indication information concerning the character of the fatty acids of the oil or fat and in particular regarding the solubility of their soaps in water. The higher the saponification number of the oil, the more soluble the soap that can be made from it [6]. Seed oils of pumpkin, Jatropha curcas (L), Persea gratesima, Butyrospermum parkii, and Lophira lanceolata, Sterculia setegera, Detarium microcarpum, Blighia, sapida and Schorocarya birrea have been reported to have saponification numbers $(\mathrm{mg} \mathrm{KOH} / \mathrm{g})$ of $190.69 \pm 1.40$ [12], 195.10 \pm 3.00 [5], 106.60 [9], and 223, 219, 212.8, 123.3, 261 and 199.3 [19]. In this study, only the oil of bird pepper variety of Capsicum frutescens has a relatively high saponification number of $187.935 \pm 0.21 \mathrm{mg} \mathrm{KOH} / \mathrm{g}$ thus it is the only oil that may be of use in soap and shampoo manufacturing industries amongst the Capsicum annum and Capsicum frutescens oils.

The percentage unsaponifiable matter obtained for the oils in this study was in the range $42.400 \pm 0.05$ $-1.780 \pm 0.11$. The unsaponifiable matter of oil is a small portion of oil which is extracted by organic solvent after the oil is saponified by alkali. Tocopherols produced for sale are from soybean, sunflower, palm and other plant unsaponifiable matter while most of the world supply of corticosteroids and sex hormones is produced from soybean oil unsaponifiable mater [8]. Percentage unsaponifiable matter content values of $5.73 \pm 0.02$ [12], $1.51 \pm 0.08$ [13], 1.95 and 1.19 [8] have been reported respectively for seed oils of pumpkin, passion fruit, Pentaclethra macrophylla and Carapa procera.

Table 2 showed the result for the mineral composition of Capsicum annum and Capsicum frutescens oils. The Na/K ratio for sweet pepper variety of Capsicum annum, bell pepper variety of Capsicum annum, bird eye chilli pepper variety of Capsicum frutescens and bird pepper variety of Capsicum frutescens are 0.077, $0.124,0.037$ and 0.034 respectively as deducted from Table 2 .

Sodium (Na) is an important mineral that assist in the regulation of body fluid and in the maintenance of electric potential in the body tissue [20]. It also helps in proper functioning of the muscles and nerves [21]. Potassium is the most abundant mineral in the Capsicum annum and Capsicum frutescens oils investigated in this study. Potassium is important in the regulation of heart beat, neurotransmission and water balance of the body [20]. Potassium is an essential nutrient and has an important role in the synthesis of amino acids and proteins [22]. High amount of potassium in the body was reported to increase iron utilization and beneficial to people taking diuretics to control hypertension and suffer from excessive excretion of potassium through the body fluid [21]. The presence of $\mathrm{Na} / \mathrm{K}$ in the body is useful for intercellular activities, maintenance of the osmotic balance of the body fluid protect the body from excessive fluid loss and involved in the contraction of muscle cells and impulse conduction along nerve fibers. $\mathrm{Na} / \mathrm{K}$ in the body is also useful in the prevention of high blood pressure. $0.6 \mathrm{Na} / \mathrm{K}$ ratio is recommended for an hypertensive patient [23]. The $\mathrm{Na} / \mathrm{K}$ ratio obtained for the Capsicum annum and Capsicum frutescens oils in this study are below 0.6 and thus suggesting that the oils would inhibit blood pressure.

The values obtained for Potassium $(\mathrm{K})$, Magnesium $(\mathrm{Mg})$ and Iron $(\mathrm{Fe})$ for the oils fall in the range of Recommended Dietary Allowance (RDA) for these minerals and indeed, the values obtained for Magnesium in bird eye chilli pepper and bird pepper varieties of Capsicum frutescens surpasses the RDA for Magnesium. The RDA for $\mathrm{K}, \mathrm{Mg}$ and Fe are 5-80mg, $0.6-60 \mathrm{mg}$ and $6-18 \mathrm{mg}$ respectively [24]. Magnesium is necessary for the release of parathyroid hormone and for its action in the backbone, kidney and intestine and for the reactions involve in converting vitamin D to its active form [21]. Magnesium plays a significant role in carbohydrate metabolism, nucleic acids and binding agents of cell wall [23]. Magnesium deficiency results in uncontrollable twisting of muscles leading to convulsion and tetanus which may both lead to death [21]. Iron has been reported as an essential trace metal that plays numerous biochemical roles in the body including oxygen - binding hemoglobin and acts as an important catalytic center in many enzymes for example, the cytochrome [23]. Iron deficiency results in anaemia which impairs muscles metabolism, iron deficiency in children result in impaired learning ability and behavioural problems.

The values obtained for the other minerals detected in the oils fall below RDA but it is good enough that these minerals are present in these oils. The mineral composition of Capsicum annum and Capsicum frutescens oils result has shown that these oils are rich sources of Iron $(\mathrm{Fe})$, Magnesium $(\mathrm{Mg})$ and Potassium $(\mathrm{K})$ and the dietary consumption of the oils would be of nutritional advantage as well as health promoting and deficiency diseases management qualities. 


\section{Conclusion}

The low acid values and low free fatty acid values obtained in this study for the oils are markers of an acceptable initial quality for the oils. The Capsicum annum and Capsicum frutescens oils are thus edible oils and can be used for cooking purposes, and sources of raw materials for industries. The oils may also found use in industries requiring non-drying oils.

Capsicum annum and Capsicum frutescens oils have also been shown to be rich sources of Iron (Fe), Magnesium (Mg) and Potassium (K) and thus these oils have nutritional, health promoting and deficiency diseases management qualities. The dietary consumption of these oils would be of advantage.

The results of this study showed that Capsicum annum and Capsicum frutescens oils possess characteristics comparable to conventional plant seed oils.

\section{References}

[1] C.O. Nwokem, E.B Agbaji, J.A. Kagbu and E.J. Ekanem. Determination of capsaicin content and Pungency Level of Five Different Peppers Grown in Nigeria. New York Journal, 3 (9), 2010, 17 - 21.

[2] A.O. Raji, K.O. Falade and F.W. Abimbolu. Effect of sucrose and binary solution on osmotic dehydration of bell pepper (Chilli) (Capsicum spp) varieties. Journal of Food Science and Technology, 47(3), 2010, 305-309.

[3] I. Ogunlade, A.A. Alebiosu and A.I. Osasona. Proximate, mineral composition, antioxidant activity and total phenotic content of some pepper varieties. International Journal of Biological and Chemical Sciences, 6 (8), 2012, 2221 - 2227.

[4] C.P. Tan and Y.B. Che Man. Differential Scanning Calorimetric Analysis of Edible Oils. Comparison of Thermal Properties and Chemical Composition. Journal of American Oil Chemists’ Society,77, 2000, 143 - 155.

[5] A.E. Ugbogu, E.I. Akubugwo, F.O Uhegbu, C.G. Chinyere, O.C. Ugbogu and K.A. Oduse. Nutritional and Chemical Composition of Jatropha curcas (L) seed oil from Nigeria. International Journal of Biosciences, 3 (8), 2013, 125 - 134.

[6 ] T.O. Siyanbola, O.O. James, C.O. Eromosele, A.A. Akinsiku, O.C. Nwinyi, A. Edobor - Osoh, A.O. Enebe, W.U. Anake and A.A. Falomo. Physicochemical analysis, phytochemical screening and antimicrobial activities of some vegetable oils from Ogun State, Nigeria. International Journal of Current Research 5(04), 2013, 992 - 997.

[7 ] M.S. Jamil, R. Nadeem, M.A. Hanif, M.A. Ali and A.K. Akhtar. Proximate composition and mineral profile of eight different unstudied data (Phoenix dactylifera L.) varieties from Pakistan. Journal of Biotechnology, 9 (22), 2010, 3252 - 3259.

[8 ] K. Minzangi, A.N. Kaaya, f. Kanslime, J.R.S. Tabuti and B. Samvura. Oil Contentand Physicochemical Characteristics of wild oil seed plants from Kiru region. Eastern Democratic Republic of Congo. African Journal of Biotechnology, 10 (2), 2011, 189 - 195.

[9] N.A. Obasi, J. Ikadilonu, E. Eze, E.I Akubugwo and U.C Okorie. Proximate Composition, Extraction, Characterization and Comparative Assessment of Coconut (Cocos nucifera), and Melon (Colocynthis citrullus) seeds and seed oils. Pakistan Journal of Biological Sciences, 15 (1), 2012, 1-9.

[10] A.O.A.C., Official Methods of Analysis. Association of Official Analytical Chemists. $16^{\text {th }}$ Edition, 1995 Washington, D.C.

[11] M.K Gafar, A.U. Itodo and D.S. Senchi. Nutritive and Antinutritive composition of Chanca pledra. Food and Public Health, 2(2), 2012, 21-27.

[12] A. G. Ardabili, R. Rarhoosh and M.H. Haddad Khodaparast. Chemical Composition and Physicochemical Properties of Pumpkin Seeds (Curcurbita pepo Subsp pepo Var. styriaka) Grown in Iran. Journal of Agriculture \& Science and Technology, 13, 2011, 1053-1063.

[13] C.R. Malacrida and N. Jorge. Yellow Passion Fruit Seed Oil (Passiflora edulis f. flavicarpa): Physical and Chemical Characteristics. Brazilian Archives of Biology and Technology, 55 (1), 2012,127-134.

[14] O.A. Fabunmi, Z.D. Osunde, B.A. Alabadan and A.A. Jigam. Characterization of Desma (Novella pentadesma) seed and oil. International Journal of Engineering and Applied Sciences, 2 (1), 2013, 71-79.

[15] O. Duduyemi, S.A. Adebanjo and K. Oluoti. Extraction and Determination of Physicochemical properties of watermelon seed oil (Citrullus lanatus L) for Relevant uses. Internationa Journal of Scientific \& Technology Research, 2(8), 2013,66 - 68

[16] N.K. Preeti, J. Sudesh and G. Rajni. Fatty acid composition and Physicochemical Characteristics of cooking oils and their blends. Journal of Dairying, Foods \& Home Science, 26 (3/4), 2007, 202 - 208.

[17] R. Indra, R.K. Bachheti and J. Archana. Chemical Composition, mineral and nutritional value of wild Bischofia jaranica seed. International Food Research Journal, 20(4), 2013, 1747 - 1751.

[18] U.N Ekwenye. Nutrient Composition of Palm Oil from Different Varieties of Oil Palm and Health. Journal of Food Technology, 4(3), 2006, 172-173

[19] M.Z. Kyari. Extraction and Characterization of seeds oils. International Agrophysics, 22, 2008 139-142.

[20] J. Alinnor and R. Oze. Chemical Evaluation of the Nutritive value of Pentaclethra macrophylla benth (African Oil Bean) Seeds. Pakistan Journal of Nutrition, 10 (4), 2011, 355 - 359.

[21] C.M. Elinge, A. Muhammad, F.A. Atiku, A.U, Itodo, I.J. Peni, O.M. Sanni and A.N. Mbongo. Proximate, Mineral and Antinutrient Composition of Pumpkin (Curcurbita pepo L) Seeds Extract. International Journal of Plant Research, 2(8), 2012, 146 - 150.

[22] G.E. Nwofia, P. Ojimelukwe and C. Eji. Chemical Composition of Leaves, Fruit, Pulp and Seeds in some Carica papaya (L) Morphotypes. International Journal of Medicinal Aromatic Plants 2(1), 2012, 200 - 206.

[23] B.K. Paul, M.M Saleh - e - In, A. Ara and S.K. Roy. Minerals and nutritional composition of radhuni (Carum roxburghianum Benth) seeds. International Food Research Journal, 20(4), 2013, 1731-1737.

[24] P.K. Emebu and J.U. Anyika. Proximate and mineral composition of Kale (Brassica oleracea) grown in Delta State, Nigeria. Pakistan Journal of Nutrition, 10(2), 2011, 190-194. 